\title{
Exogenous GH infusion to late-gestational fetal sheep does not alter fetal growth and metabolism
}

\author{
M K Bauer, J E Harding, B H Breier and P D Gluckman \\ Research Centre for Developmental Medicine and Biology, School of Medicine, Private Bag 92019, Auckland, New Zealand \\ (Requests for offprints should be addressed to J E Harding; Email: j.harding@auckland.ac.nz) \\ (M K Bauer is now at Novo Nordisk A/S, Pharmacological Research 3, Pharmacology Health Care Discovery and Preclinical Development, Novo Nordisk Park, \\ 2670 Maaloev, Denmark)
}

\begin{abstract}
The role of $\mathrm{GH}$ in the regulation of fetal growth and metabolism in late gestation is not well defined. The aim of this study was to determine the effects of exogenous $\mathrm{GH}$ infusion on fetal growth and feto-placental metabolism in the normally growing late-gestation fetal sheep. Eleven fetuses received pulsatile $\mathrm{GH}$ infusion $(3.5 \mathrm{mg} /$ day $)$ for 10 days while 12 control fetuses received vehicle. The GH infusion was given as a continuous infusion $(2.5 \mathrm{mg} /$ day $)$ plus an additional pulsatile component ( 30 pulses equivalent to $1 \mathrm{mg}$ /day) designed to mimic the natural pattern of $\mathrm{GH}$ secretion. Fetal $\mathrm{GH}$ infusion raised the circulating fetal concentrations of GH threefold, but did not change fetal concentrations of IGF-I, IGF-binding protein-3, insulin or ovine placental lactogen. GH-treated fetuses had blood urea concentrations 15\% lower than controls $(P<0 \cdot 05)$ and glucose uptake $18 \%$ lower per $\mathrm{kg}$ fetal
\end{abstract}

weight $(P=0 \cdot 06)$. There were no other differences attributable to fetal GH infusion in feto-placental metabolism, placental function or placental blood flow. GHtreated fetuses were larger than controls at postmortem (weight $+13 \%, P<0 \cdot 01$; girth $+5 \%, P<0 \cdot 01$; crown-rump length $+3 \%, P<0 \cdot 05)$. However, there were no differences between groups in measures of fetal growth (increment in chest girth and hindlimb length). GH-treated fetuses had heavier mothers and when maternal weight was included as a covariate in the analysis, there was no significant difference between treatment groups that could be attributed to $\mathrm{GH}$ treatment. $\mathrm{GH}$ infusion to normal fetal sheep does not appear to have a significant effect on feto-placental metabolism or fetal growth.

Journal of Endocrinology (2000) 166, 591-597

\section{Introduction}

Growth hormone $(\mathrm{GH})$ has been shown to be a major endocrine regulator of postnatal growth and intermediary metabolism. However, its role in fetal life is less clear. Despite general acceptance of the dogma that GH does not regulate fetal growth in utero, there is increasing experimental evidence that GH may have at least some role in fetal growth in late gestation. GH-deficient dwarf rat fetuses have proportionately reduced body size (Kim et al. 1993), while human fetuses with congenital GH deficiency are born relatively short (Gluckman et al. 1992). In fetal sheep, hypophysectomy results in reduced length of the limbs and long bones which was not reversed by thyroid hormone replacement (Mesiano et al. 1987), although the replacement may not have been completely adequate in this study.

There is also indirect evidence that fetal GH may have a role in feto-placental metabolism. Hypophysectomised fetal sheep have markedly increased fat deposition which is reversed by fetal $\mathrm{GH}$ replacement using a crude pituitary preparation (Stevens \& Alexander 1986). GH receptor mRNA is present in both hepatic and extrahepatic tissues in the late-gestation fetal sheep, including muscle and kidney (Klempt et al. 1993). Circulating GH concentrations in late-gestation fetal sheep are also sensitive to factors similar to those thought to be important for $\mathrm{GH}$ regulation in postnatal life, including $\mathrm{GH}-$ releasing hormone (Gluckman 1984), somatostatin (Gluckman et al. 1979), free fatty acids (Bassett \& Gluckman 1987) and undernutrition (Bauer et al. 1995). GH in the maternal circulation may also influence placental function and feto-placental substrate distribution (Harding et al. 1997).

Despite this indirect evidence for possible roles of $\mathrm{GH}$ in fetal life, we are not aware of a study directly investigating the effects of additional fetal GH administration in utero. We therefore undertook this study to determine the effects of 10 days of exogenous GH infusion on fetal growth and feto-placental metabolism in normal lategestation fetal sheep. GH was infused in a pulsatile fashion to mimic the normal pattern of $\mathrm{GH}$ secretion in the fetal lamb (Bauer et al. 1995). 


\section{Materials and Methods}

\section{Animals}

Twenty-three Romney Dorset cross-bred ewes with singleton pregnancies of known gestational age were brought to the laboratory at approximately 105 days of gestation. They were housed in individual metabolic cages with free access to water and concentrates.

At 115 days (range 113-117 days) ewes underwent surgery as described previously (Harding et al. 1997). Briefly, hysterotomy was performed under general anaesthetic. Catheters were placed in the fetal femoral artery and vein via the tarsal vessels and the common umbilical vein via a para-umbilical incision. Two growth-measuring devices (growth catheters) were placed, one around each half of the fetal chest from sternum to spine (Mellor \& Murray 1982). Catheters were also placed in the uterine vein via the utero-ovarian vein draining the pregnant horn, and maternal carotid artery and jugular vein and the maternal femoral artery and vein via the tarsal vessels.

Antibiotics $(250 \mathrm{ml}$ streptomycin and $250 \mathrm{ml}$ penicillin; Streptopen, Pitman Moore, Upper Hutt, New Zealand) were given intramuscularly to the ewe and $80 \mathrm{mg}$ gentamycin intravenously to the fetus at the time of surgery and thereafter daily for the next 3 days. Catheters were flushed on alternate days with saline containing $10 \mathrm{IU} / \mathrm{ml}$ heparin. Growth catheters were measured twice daily after the ewe had been standing quietly for several minutes, and the mean of the two measurements was recorded.

At the end of the experiment (125-128 days) ewes were killed with an overdose of phenobarbitone. The uterus and its contents were dissected, weighed and measured. The position of all catheters was confirmed. All procedures were approved by the Institutional Animal Ethics Committee.

\section{Experimental procedures}

As soon as ewes had recovered consciousness after anaesthesia, fetuses in the $\mathrm{GH}$ treatment group began a 10-day pulsatile intravenous infusion of recombinant bovine $\mathrm{GH}$ (batch no. PR003; American Cyanamid, Princeton, NJ, USA). The GH was freshly prepared in carbonatebuffered saline, $\mathrm{pH} 9.4$ (containing $145 \mathrm{mM} \mathrm{NaCl}$, $31.5 \mathrm{mM} \mathrm{NaHCO}_{3}, 10 \cdot 7 \mathrm{mM} \mathrm{Na}_{2} \mathrm{CO}_{3}$ ). The total daily dose was $3.5 \mathrm{mg}$, given as a continuous infusion of $2.5 \mathrm{mg}$ $(1 \mathrm{ml} / \mathrm{h})$ plus an additional $1 \mathrm{mg}$ divided as 30 superimposed pulses $(330 \mu \mathrm{l} /$ pulse). This pulsatile infusion was designed to mimic the natural secretion of $\mathrm{GH}$ (Bauer et al. 1995). Control animals received an identical volume of the vehicle (carbonate-buffered saline). Blood samples $(4 \mathrm{ml})$ were taken from the fetus and ewe in the morning before feeding on alternate days for metabolic and hormone measurements. On day 7, five samples were taken at 15-min intervals for measurement of mean $\mathrm{GH}$ concentration.
On day 10, GH feto-placental substrate uptakes were measured in five pairs of samples taken over an hour starting $2 \cdot 5 \mathrm{~h}$ after cessation of the $\mathrm{GH}$ infusion. The $\mathrm{GH}$ infusion had to be stopped as fetal venous access was limited. A solution containing $110 \mathrm{mg}$ antipyrine, $750 \mu \mathrm{Ci}$ 3-O-[meth $\left.y l-{ }^{3} \mathrm{H}\right]$ glucose and $120 \mu \mathrm{Ci}\left[{ }^{14} \mathrm{C}\right]$ urea in normal saline was infused via a $0 \cdot 45 \mu \mathrm{m}$ filter to the fetus via the fetal venous catheter at $3 \mathrm{ml} / \mathrm{h}$ for $3.5 \mathrm{~h}$ after a $5 \mathrm{ml}$ bolus. After $150 \mathrm{~min}$ of infusion to establish a steady state, five sets of blood samples were taken at 15-min intervals. Each set consisted of samples taken from the maternal artery $(2.7 \mathrm{ml})$, uterine vein $(2.7 \mathrm{ml})$, umbilical vein $(1.3 \mathrm{ml})$ and fetal artery $(1.3 \mathrm{ml})$. All blood samples for metabolic measurements were aliquoted into Eppendorf tubes on ice and immediately frozen at $-70{ }^{\circ} \mathrm{C}$ until assay. Blood for hormone and free fatty acid measurements was centrifuged at $4{ }^{\circ} \mathrm{C}$ and plasma separated and frozen at $-70{ }^{\circ} \mathrm{C}$ until assay. Samples for blood gas measurements were kept in capped syringes on ice until measurements were made within 30 min using a blood gas analyser (Chiron M845; Chiron Corporation, Emeryville, CA, USA).

\section{Assays}

Glucose (Kunst et al. 1984) and urea (Kerscher \& Ziegenhorn 1985) were measured by standard enzymatic colorimetric methods modified for assay using a 96-well plate reader (Ashour et al. 1987). Lactate was measured in microplates using an enzymatic procedure based on the reduction of NAD. Amino nitrogen was assayed by colorimetric reaction with $\beta$-napthoquinone sulphonate (Evans et al. 1993). Free fatty acids were measured by a modification of a commercial kit assay (Oliver et al. 1995). Antipyrine was measured in duplicate by HPLC (Pimentel et al. 1986). $\left[{ }^{14} \mathrm{C}\right]$ Urea and 3-O- $\left[\right.$ meth $\left.y l-{ }^{3} \mathrm{H}\right]$ glucose activities were determined in duplicate aliquots of blood deproteinised with sulphuric acid and sodium tungstate and counted in a dual channel liquid scintillation counter (Rak-Beta model 1219; LKB Wallac, Turku, Finland) with external standard quench correction for $10 \mathrm{~min}$ or to a d.p.m. error of less than 3\%. Insulin-like growth factor-I (IGF-I) was measured by double-antibody radioimmunoassay (RIA) after acid-ethanol cryoprecipitation extraction validated for fetal sheep plasma (Breier et al. 1994a). Insulin (Oliver et al. 1993) and ovine placental lactogen (Oliver et al. 1992) were measured by RIA. Ovine IGF-binding protein-3 (IGFBP-3) was measured by RIA (Gallaher et al. 1998).

\section{Data analysis}

Blood oxygen content was calculated from measured haemoglobin, oxygen saturation, and $\mathrm{p}_{2}$ (Gull \& Charlton 1993). Blood flows were calculated from measuring antipyrine concentrations according to the Fick principle (Meschia et al. 1966). Uptakes of oxygen, glucose, and 


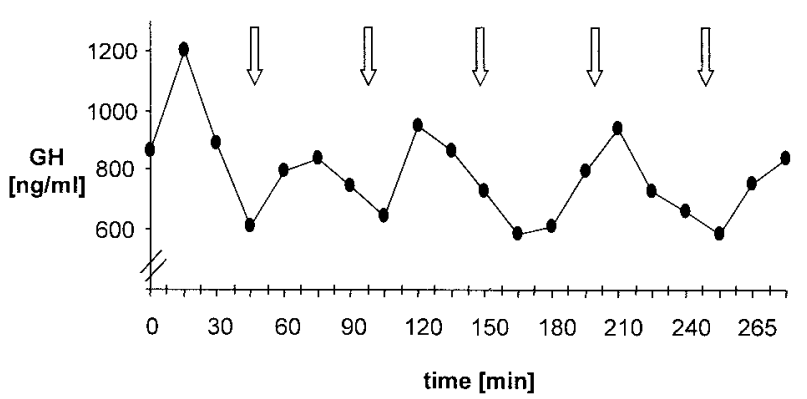

Figure $1 \mathrm{GH}$ profile of an individual fetus on day 7 of $\mathrm{GH}$ infusion. GH was infused at a constant rate of $2.5 \mathrm{mg} / \mathrm{fetus}$ per day. GH pulses (arrows) were superimposed at 48-min intervals ( $1 \mathrm{mg} /$ fetus per day). Samples for $\mathrm{GH}$ analysis were taken every $15 \mathrm{~min}$.

lactate were calculated for the uterus and its contents (referred to as uterine uptake $=$ maternal artery - uterine vein concentration difference $\times$ uterine blood flow), fetus (umbilical vein - femoral artery concentration difference $\times$ umbilical blood flow) and placenta (uterine uptake - fetal uptake). Clearances of $\left[{ }^{14} \mathrm{C}\right]$ urea and 3-O$\left[\right.$ meth $\left.y l-{ }^{3} \mathrm{H}\right]$ glucose were calculated by steady-state diffusion techniques (Kulhanek et al. 1974, Stacey et al. 1978). Fetal urea production rate was calculated as the product of $\left[{ }^{14} \mathrm{C}\right]$ urea clearance and the (fetal artery - maternal artery) urea concentration difference (Gresham et al. 1972, Battaglia \& Meschia 1986). All uptakes are expressed relative to tissue weights, i.e. fetal uptakes per kg fetus, placental uptakes per kg placenta and uterine uptakes per $\mathrm{kg}$ uterus and contents.

All baseline measurements and postmortem measurements were compared using unpaired $t$-tests and analysis of covariance as appropriate. Metabolite and hormone concentrations over the period of the study were tested for $\mathrm{GH}$ effects by repeated measures analysis of variance. Not all data were available for every animal at each time-point, largely because catheters failed to sample. Differences in growth rates (chest girth increments) were tested using regression analysis as described previously (Harding 1997).

All values are given as the means \pm S.E.M. Statistical analyses were carried out using the SPSS software package (SPSS version 7·0; SPSS Inc., Chicago, IL, USA).

\section{Results}

Fetal GH infusion attained a pulsatile plasma GH profile (Fig. 1), and raised mean circulating fetal GH concentrations threefold (Table 1). Maternal GH concentrations were not changed by fetal GH treatment. Fetal and maternal circulating concentrations of IGF-I, IGFBP-3, insulin and placental lactogen were not altered by fetal GH infusion (Table 1).

GH-treated fetuses had lower blood urea concentrations than controls and higher maternal oxygen concentrations.

Table 1 Effect of a 10-day fetal GH infusion on fetal and maternal hormone concentrations. Values are means \pm S.E.M. $(n)$ expressed in $\mathrm{ng} / \mathrm{ml}$

\begin{tabular}{|c|c|c|}
\hline & GH & Control \\
\hline \multicolumn{3}{|l|}{ Fetal } \\
\hline $\mathrm{GH}$ & $694 \pm 47(6)$ & $201 \pm 42^{\star * *}(6)$ \\
\hline IGF-I & $93 \pm 10(11)$ & $102 \pm 9(11)$ \\
\hline Insulin & $0 \cdot 73 \pm 0 \cdot 14(6)$ & $1 \cdot 00 \pm 0 \cdot 15(5)$ \\
\hline Placental lactogen & $10 \cdot 5 \pm 2 \cdot 7(6)$ & $10 \cdot 9 \pm 2 \cdot 4(7)$ \\
\hline IGFBP-3 & $941 \pm 83(6)$ & $833 \pm 65(7)$ \\
\hline \multicolumn{3}{|l|}{ Maternal } \\
\hline $\mathrm{GH}$ & $4 \cdot 4 \pm 0 \cdot 5(6)$ & $7 \cdot 5 \pm 1 \cdot 0(7)$ \\
\hline IGF-I & $185 \pm 14(11)$ & $172 \pm 15(11)$ \\
\hline Insulin & $1 \cdot 06 \pm 0 \cdot 45(6)$ & $0 \cdot 83 \pm 0 \cdot 21(7)$ \\
\hline Placental lactogen & $228 \pm 57(6)$ & $165 \pm 20(7)$ \\
\hline IGFBP-3 & $1760 \pm 173(6)$ & $1552 \pm 120(7)$ \\
\hline
\end{tabular}

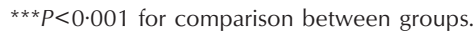

There were no differences between groups in fetal or maternal blood glucose, lactate, amino nitrogen or fatty acid concentrations (Table 2).

There was no difference between the GH-treated and control group in umbilical blood flow $(174 \pm 11$ vs $193 \pm 12 \mathrm{ml} / \mathrm{min}$ per $\mathrm{kg}$ ) or uterine blood flow (911 \pm 92 vs $1191 \pm 123 \mathrm{ml} / \mathrm{min}$ per $\mathrm{kg}$ ), nor in placental clearance of $\left[{ }^{14} \mathrm{C}\right]$ urea $(129 \pm 16$ vs $116 \pm 17 \mathrm{ml} / \mathrm{min}$ per $\mathrm{kg})$ or 3-O-[methyl- $\left.{ }^{3} \mathrm{H}\right]$ glucose $(168 \pm 22 \mathrm{vs} 164 \pm 26 \mathrm{ml} /$ min per $\mathrm{kg}$ ). Fetal glucose uptake per $\mathrm{kg}$ fetal weight tended to be lower $(P<0 \cdot 06)$ and placental amino nitrogen uptake was reduced in the GH-treated group. There were no other differences between groups in fetal, uterine or placental uptakes of glucose, lactate, amino nitrogen or oxygen (Table 3 ). Fetal urea production was not altered by $\mathrm{GH}(12 \cdot 8 \pm 2 \cdot 6$ vs $13 \cdot 2 \pm 3 \cdot 7 \mu \mathrm{mol} / \mathrm{min}$ per $\mathrm{kg})$.

Table 2 Effect of a 10-day fetal GH infusion on fetal and maternal blood metabolite concentrations. Values are means \pm S.E.M. $(n)$ expressed in $\mathrm{mmol} / \mathrm{l}$

GH

Fetal

Glucose

Lactate

Amino nitrogen

Urea

Free fatty acids

Oxygen

Maternal

Glucose

Lactate

Amino nitrogen

Urea

Free fatty acids

Oxygen
$0 \cdot 87 \pm 0 \cdot 05(11)$

$1 \cdot 45 \pm 0 \cdot 18(11)$

$6 \cdot 84 \pm 0 \cdot 20(11)$

$5 \cdot 59 \pm 0 \cdot 32(11)$

$0.043 \pm 0.007$ (6)

$3 \cdot 38 \pm 0 \cdot 26(10)$

$2 \cdot 48 \pm 0.08(11)$

$0 \cdot 72 \pm 0.07(11)$

$4 \cdot 74 \pm 0 \cdot 28(11)$

$4 \cdot 80 \pm 0 \cdot 34(11)$

$0 \cdot 57 \pm 0.08(6)$

$6 \cdot 40 \pm 0 \cdot 23(9)$
Control

$0 \cdot 82 \pm 0.07(11)$

$1 \cdot 59 \pm 0 \cdot 12(11)$

$6 \cdot 80 \pm 0 \cdot 23(11)$

$6 \cdot 59 \pm 0 \cdot 36^{*}(11)$

$0 \cdot 041 \pm 0.005$ (7)

$3 \cdot 36 \pm 0 \cdot 16(9)$

$2 \cdot 67 \pm 0.09(11)$

$0 \cdot 75 \pm 0.04(11)$

$4 \cdot 63 \pm 0 \cdot 30(11)$

$5 \cdot 86 \pm 0 \cdot 44(11)$

$0 \cdot 44 \pm 0.08(7)$

$5 \cdot 55 \pm 0 \cdot 28^{*}(6)$

${ }^{*} P<0 \cdot 05$ for comparison between groups. 
Table 3 Effect of a 10-day fetal GH infusion on fetal, uterine and placental substrate uptakes. Values are means \pm S.E.M. $(n)$ expressed in $\mu \mathrm{mol} / \mathrm{min}$ per $\mathrm{kg}$

\begin{tabular}{|c|c|c|}
\hline & GH & Control \\
\hline \multicolumn{3}{|l|}{ Fetal } \\
\hline Glucose & $24 \cdot 7 \pm 1 \cdot 6(11)$ & $30 \cdot 1 \pm 2 \cdot 2 \dagger(11)$ \\
\hline Lactate & $28 \cdot 9 \pm 4 \cdot 0(11)$ & $23 \cdot 1 \pm 2 \cdot 1(11)$ \\
\hline Amino nitrogen & $13 \cdot 8 \pm 17 \cdot 9(11)$ & $48 \cdot 7 \pm 17 \cdot 3(11)$ \\
\hline Oxygen & $300 \pm 17(10)$ & $305 \pm 16(9)$ \\
\hline \multicolumn{3}{|l|}{ Uterine } \\
\hline Glucose & $58 \cdot 2 \pm 4 \cdot 4(9)$ & $73 \cdot 0 \pm 8 \cdot 8(7)$ \\
\hline Lactate & $16 \cdot 0 \pm 4 \cdot 6(7)$ & $5 \cdot 3 \pm 4 \cdot 3(7)$ \\
\hline Amino nitrogen & $23 \cdot 9 \pm 13 \cdot 2(9)$ & $-0 \cdot 3 \pm 18 \cdot 9(7)$ \\
\hline Oxygen & $434 \pm 47(8)$ & $455 \pm 98(5)$ \\
\hline \multicolumn{3}{|l|}{ Placental } \\
\hline Glucose & $444 \pm 55(9)$ & $605 \pm 105(7)$ \\
\hline Lactate & $-346 \pm 60(7)$ & $-236 \pm 56(7)$ \\
\hline Amino nitrogen & $-204 \pm 153$ & $521 \pm 284^{*}(9)$ \\
\hline Oxygen & $702 \pm 117(8)$ & $780 \pm 364(4)$ \\
\hline
\end{tabular}

$\dagger P=0 \cdot 06 ;{ }^{*} P<0 \cdot 05$ for comparison between groups.

At the end of the experiment, GH-treated fetuses were found to be larger than controls. They were heavier, longer, had greater girths and heavier liver, kidney, gut, thymus and placenta (Table 4). When expressed per $\mathrm{kg}$ fetal weight, the GH-treated fetuses had relatively smaller brains, hearts and pituitaries but no differences were found in any other organ weights or body measurements.

Table 4 Effect of a 10-day fetal GH infusion on fetal and placental size. Values are means \pm S.E.M. for $10 \mathrm{GH}$-treated and 12 control animals unless otherwise specified

\begin{tabular}{|c|c|c|}
\hline & GH & Control \\
\hline Gestational age (days) & $126 \pm 0 \cdot 4$ & $126 \pm 0 \cdot 3$ \\
\hline Crown-rump length $(\mathrm{cm})$ & $41 \cdot 9 \pm 0 \cdot 3$ & $40 \cdot 8 \pm 0 \cdot 4^{*}$ \\
\hline Hindlimb length (cm) & $31 \cdot 2 \pm 1 \cdot 5$ & $30 \cdot 7 \pm 0 \cdot 3$ \\
\hline Hock-hoof length (cm) & $19 \cdot 3 \pm 1 \cdot 4$ & $17 \cdot 1 \pm 0 \cdot 2$ \\
\hline Girth (cm) & $33 \cdot 0 \pm 0 \cdot 3$ & $31 \cdot 4 \pm 0 \cdot 5^{* *}$ \\
\hline Fetus (g) & $3842 \pm 93$ & $3341 \pm 136^{* *}$ \\
\hline Brain (g) & $42 \cdot 6 \pm 1 \cdot 2$ & $40 \cdot 9 \pm 1 \cdot 1$ \\
\hline Heart (g) & $25 \cdot 4 \pm 0 \cdot 8$ & $24 \cdot 0 \pm 1 \cdot 0$ \\
\hline Pituitary (mg) & $84 \cdot 8 \pm 5 \cdot 6$ & $92 \cdot 5 \pm 3 \cdot 5$ \\
\hline Lungs (g) & $103 \cdot 2 \pm 5 \cdot 1$ & $97 \cdot 7 \pm 4 \cdot 2$ \\
\hline Liver $(\mathrm{g})$ & $154 \cdot 6 \pm 10 \cdot 9$ & $127 \cdot 0 \pm 7 \cdot 7^{*}$ \\
\hline Spleen (g) & $10 \cdot 2 \pm 0 \cdot 7$ & $8 \cdot 5 \pm 0 \cdot 5$ \\
\hline Kidneys (g) & $32 \cdot 9 \pm 1 \cdot 4$ & $28 \cdot 9 \pm 1 \cdot 4^{*}$ \\
\hline Gut (g) & $93 \cdot 9 \pm 4 \cdot 8$ & $80 \cdot 2 \pm 3 \cdot 9^{*}$ \\
\hline Pancreas (g) & $3 \cdot 9 \pm 0 \cdot 3(n=7)$ & $4 \cdot 0 \pm 0 \cdot 3(n=6)$ \\
\hline Adrenals (g) & $0 \cdot 40 \pm 0 \cdot 03$ & $0 \cdot 36 \pm 0 \cdot 03$ \\
\hline Thyroid (g) & $0 \cdot 9 \pm 0 \cdot 1$ & $1 \cdot 0 \pm 0 \cdot 1(n=11)$ \\
\hline Thymus (g) & $15 \cdot 7 \pm 1 \cdot 5$ & $12 \cdot 0 \pm 0 \cdot 7^{*}(n=11)$ \\
\hline Placenta (g) & $496 \pm 18$ & $416 \pm 31^{*}$ \\
\hline Uterus (g) & $814 \pm 60$ & $710 \pm 35$ \\
\hline Membranes (g) & $440 \pm 82(n=9)$ & $427 \pm 81$ \\
\hline
\end{tabular}

${ }^{*} P<0 \cdot 05,{ }^{*} P<0 \cdot 01$ for comparison between groups before correction for maternal weight.
Table 5 Measurements made at surgery. Values are means \pm S.E.M. for $10 \mathrm{GH}$-treated and 12 control animals

\begin{tabular}{|c|c|c|}
\hline & GH & Control \\
\hline Gestational age (days) & $115 \pm 0 \cdot 5$ & $115 \pm 0 \cdot 4$ \\
\hline Maternal weight (kg) & $62 \cdot 7 \pm 1 \cdot 9$ & $56 \cdot 4 \pm 1 \cdot 4^{* *}$ \\
\hline Fetal sex (male:female) & $8: 2$ & $5: 7$ \\
\hline Fetal girth $(\mathrm{cm})$ & $23 \cdot 8 \pm 2 \cdot 3$ & $24 \cdot 9 \pm 0 \cdot 6$ \\
\hline Fetal hindlimb length $(\mathrm{cm})$ & $29 \cdot 3 \pm 0 \cdot 3$ & $27 \cdot 4 \pm 0 \cdot 6^{* *}$ \\
\hline Fetal hock-hoof length $(\mathrm{cm})$ & $15 \cdot 0 \pm 0 \cdot 2$ & $14 \cdot 1 \pm 0 \cdot 3^{*}$ \\
\hline
\end{tabular}

However, we found that GH-treated animals had heavier mothers and the fetuses were larger at surgery, as indicated by fetal limb length measurements at that time (Table 5). There was also a trend towards more male fetuses in the GH-treated group ( 80 vs $42 \%, P=0 \cdot 07$ ). Fetal size was directly correlated with maternal weight over the whole group of animals (Table 6). When this was taken into account by including maternal weight as a covariate, fetal size and organ weights were no longer significantly different between groups at postmortem. The effect of fetal sex was not significant when it was added to the model. Furthermore, fetal growth rate as measured by increment in fetal girth was not changed by fetal $\mathrm{GH}$ treatment $(6 \cdot 8 \pm 0.8$ vs $6 \cdot 2 \pm 0.5 \mathrm{~mm} /$ day). Increment in fetal hindlimb length between surgery and postmortem was also not affected by GH administration $(1.9 \pm 1.4$ vs $3.3 \pm 0.4 \mathrm{~cm})$. Thus the differences between groups at postmortem were most likely due to different initial sizes rather than the effects of $\mathrm{GH}$ treatment.

\section{Discussion}

The findings of this study illustrate the importance of careful assessment of the equivalence of experimental groups, and the risks of interpreting increased final size as evidence of increased growth. Fetuses in the GH-treated groups were heavier, longer and had increased weight of a number of organs compared with control animals. However, longitudinal measures of fetal growth (increment in girth and limb length) were not affected by GH treatment. Careful data analysis revealed that this paradox was

Table 6 The relationship between fetal growth parameters and maternal weight. Values are correlation coefficients $(r)$ for 10 $\mathrm{GH}$-treated and 12 control animals

\begin{tabular}{|c|c|c|c|}
\hline & GH & Control & Whole group \\
\hline Crown-rump length & 0.05 & $0 \cdot 28$ & $0 \cdot 51^{\star \star}$ \\
\hline Hindlimb length & $0 \cdot 59$ & $0 \cdot 39$ & $0 \cdot 46^{*}$ \\
\hline Girth & $0 \cdot 06$ & $0 \cdot 56^{*}$ & $0 \cdot 53^{* *}$ \\
\hline Fetal weight & $0 \cdot 5$ & $0 \cdot 37$ & $0 \cdot 56^{* *}$ \\
\hline
\end{tabular}

${ }^{*} P<0 \cdot 05,{ }^{* *} P<0 \cdot 01$ for correlation coefficients. 
explained by the observation that the GH-treated fetuses had heavier mothers and longer limbs at the time of surgery. The relationship between fetal size and maternal constraint, which is a function of maternal size, is well recognised (Heinrich 1992, Morel et al. 1994). Thus it is most likely, since the groups differed at the beginning of the experiment, that the differences in outcome were not due to fetal GH therapy. The failure of bovine $\mathrm{GH}$ treatment to increase growth in fetal sheep cannot be ascribed to lack of biological activity of the bovine $\mathrm{GH}$ preparation used, since the same preparation induced the known metabolic and endocrine responses in adult sheep (Hennies et al. 1998).

In the rat, responses to $\mathrm{GH}$ have been shown to vary depending on the pattern of $\mathrm{GH}$ administration. $\mathrm{GH}$ injections have a more pronounced effect on total body weight gain, while a constant infusion of GH leads to selective organ growth and reduction in size of fat pads (Clark et al. 1995, 1996). The importance of pulsatile GH secretion in the fetal sheep is still unresolved. However, the pattern of circulating $\mathrm{GH}$ in our GH-treated fetuses was clearly pulsatile and in good agreement with the GH pattern we have reported in normally growing fetal sheep of similar gestational age (Bauer et al. 1995). Thus it is unlikely that the lack of effect in the present study is due to lack of GH pulsatility.

We started GH treatment immediately after surgery in order to maximise duration of treatment. It is possible that post-operative stress meant that the fetuses underwent a period of relative $\mathrm{GH}$ resistance, and that this may have contributed to the absence of observed response to $\mathrm{GH}$ treatment. However, there were no observed trends over the period of the study in any of the monitored parameters (fetal blood gases, metabolite and hormone concentrations) suggestive of resolving post-operative stress. There was also no suggestion of fetal growth rate, measured by girth increment, diverging between the groups over time, as would be expected if GH did influence fetal growth and a period of hormone resistance was resolving postoperatively.

For practical reasons, placental function was studied over an hour beginning $2.5 \mathrm{~h}$ after $\mathrm{GH}$ treatment had been stopped. It is theoretically possible that the cessation of $\mathrm{GH}$ infusion before the study contributed to the lack of observed differences between groups. However, there were no observable trends over time in any of the parameters measured in the five sets of samples taken during the study. This suggests that there was not an observable effect due to declining GH levels over this period. Furthermore, the aspect of placental function which has been shown to respond to maternal GH treatment (placental diffusion capacity, measured by $\left[{ }^{14} \mathrm{C}\right]$ urea clearance; Harding et al. 1997) is determined by structural characteristics of the placenta such as surface area and barrier thickness. These characteristics are not likely to have changed over the $3 \cdot 5$-h period of withdrawal of $\mathrm{GH}$ treatment in our study. In addition, the lack of effect of GH treatment on fetal growth, metabolic and endocrine parameters monitored throughout the entire 10-day period makes it unlikely that the lack of difference between groups in measured aspects of placental functions was due only to a brief period of $\mathrm{GH}$ withdrawal at the time of study.

Consistent with the failure of $\mathrm{GH}$ treatment to increase growth in normal fetuses is the failure of GH to markedly alter fetal metabolic profiles. In postnatal life, GH administration reduces glucose uptake and increases lypolysis (Davidson 1987) as well as increasing protein synthesis and decreasing urea production (Salomon et al. 1991). In our study, GH-treated fetuses had reduced glucose uptake per $\mathrm{kg}$ fetus and decreased blood urea concentrations, both of which are consistent with the postnatal metabolic effects of $\mathrm{GH}$. However, it is difficult to distinguish these possible $\mathrm{GH}$ effects from the altered metabolic profiles of larger fetuses of larger mothers with higher arterial oxygen contents secondary to higher haemoglobin concentrations. The lower blood urea concentrations in the GH-treated group were most likely to be secondary to similar lower maternal blood urea concentrations of well-nourished ewes, since urea crosses the placenta by simple diffusion, and fetal blood levels are thus directly related to those of the mother. This is supported by our finding of no difference in urea production per $\mathrm{kg}$ fetus between groups, as estimated by the relatively accurate measurement of $\left[{ }^{14} \mathrm{C}\right]$ urea clearance.

In contrast, fetal glucose uptake per $\mathrm{kg}$ fetus is reported to be unchanged with differing fetal size (Owens et al. 1987). Thus the difference we observed may reflect true effects of GH on glucose uptake and insulin sensitivity, since $\mathrm{GH}$ is reported to decrease insulin sensitivity in fetal (Parkes \& Bassett 1985) and postnatal lambs (Bellver et al. 1995). The lack of effect of GH treatment on fetal levels of free fatty acids may seem surprising in view of previous evidence of the effects of GH on fetal fat deposition (Stevens \& Alexander 1986). However, their studies were conducted on hypophysectomised fetuses with relative obesity. The normal fetus has relatively little white fat at the stage in development which we studied, and brown fat appears resistant to lipolysis in utero because of placental factors (Ball et al. 1995).

In summary, our study shows that pulsatile GH infusion to normal fetal sheep does not stimulate fetal growth, nor does it lead to substantial changes in fetal endocrine and metabolic profiles. These findings do not exclude a possible role for $\mathrm{GH}$ in the regulation of fetal growth and metabolism, since these experiments were only undertaken in normal fetuses. Since circulating GH concentrations are already extremely high in the normally growing fetus, it is possible that any role for $\mathrm{GH}$ in fetal growth and metabolism is already maximal in such fetuses, and cannot be further stimulated by additional GH. GH receptor concentrations are relatively low in fetal tissues, 
being approximately $30 \%$ of adult concentrations in the fetal liver at this age (Klempt et al. 1993). Thus it is probable that the receptors are already fully saturated with endogenous GH or with ovine placental lactogen, which can also bind to the ovine $\mathrm{GH}$ receptor (Breier et al. 1994b), and antagonises GH action in vitro (Herman et al. 1999).

In addition, since fetal growth in late gestation is largely limited by nutrient availability, it is possible that, in the normal fetus, additional GH will have no effect on fetal growth unless nutrient availability is also altered. Hence it remains possible that in fetuses with reduced circulating $\mathrm{GH}$ concentrations or altered fetal nutrient availability, GH supplementation may result in a demonstrable change in fetal growth and metabolism. Studies examining these questions are currently underway in our laboratory.

\section{Acknowledgements}

This work is supported by the Auckland Medical Research Foundation and the Health Research Council of New Zealand. Dr W R Baumbach (American Cyanamid, Princeton, NJ, USA) kindly provided the GH. These studies would not have been possible without the assistance and advice of Pandora Evans, Christine Gibson, Ellen Jensen, Toni Smith-Wong and Pierre van Zijl.

\section{References}

Ashour MA, Gee SJ \& Hammock BD 1987 Use of a 96-well microplate reader for measuring routine enzyme activities. Analytical Biochemistry 166 353-360.

Ball KT, Gunn TR, Power GG, Asakura H \& Gluckman PD 1995 A potential role for adenosine in the inhibition of nonshivering thermogenesis in the fetal sheep. Pediatric Research 37 303-309.

Bassett NS \& Gluckman PD 1987 The effect of fatty acid infusion on growth hormone secretion in the ovine fetus: evidence for immaturity of pituitary responsiveness in utero. Journal of Developmental Physiology 9 301-308.

Battaglia FC \& Meschia G 1986 An Introduction to Fetal Physiology, pp 109-111. London: Academic Press.

Bauer MK, Breier BH, Harding JE, Veldhuis JD \& Gluckman PD 1995 The fetal somatotropic axis during long term maternal undernutrition in sheep: evidence for nutritional regulation in utero. Endocrinology 136 1250-1257.

Bellver SP, Beermann DH, Bell AW, Van Tassell CP, Hogue DE \& McLaughlin CL 1995 Effects of exogenous somatotropin on wholebody glycemic response to insulin in young preruminant and ruminant lambs. Domestic Animal Endocrinology 12 143-156.

Breier BH, Ambler GR, Sauerwein H, Surus A \& Gluckman PD $1994 a$ The induction of hepatic somatotrophic receptors after birth in sheep is dependent on parturition-associated mechanisms. Journal of Endocrinology 141 101-108.

Breier BH, Funk B, Ambler GR, Surus A, Wells CA, Waters MJ \& Gluckman PD 1994b Characterization of ovine growth hormone (oGH) and ovine placental lactogen (oPL) binding to fetal and adult hepatic tissue in sheep: evidence that $\mathrm{oGH}$ and $\mathrm{OPL}$ interact with a common receptor. Endocrinology 135 919-928.

Clark RG, Mortensen DL, Carlsson LMS, Carmignac D \& Robinson ICAF 1995 Growth responses to patterned GH delivery. Endocrine $3717-723$.
Clark RG, Mortensen DL, Carlsson LMS, Carlsson B, Carmignac D \& Robinson ICAF 1996 The obese growth hormone (GH)deficient dwarf rat: body fat responses to patterned delivery of $\mathrm{GH}$ and insulin-like growth factor-I. Endocrinology 137 1904-1912.

Davidson MB 1987 Effect of growth hormone on carbohydrate and lipid metabolism. Endocrine Reviews 8 115-131.

Evans PC, Ffolliott-Powell FM \& Harding JE 1993 A colorimetric assay for amino nitrogen in small volumes of blood: reaction with B-naphthoquinone sulfonate. Analytical Biochemistry 208 334-337.

Gallaher BW, Breier BH, Keven CL, Harding JE \& Gluckman PD 1998 Fetal programming of insulin-like growth factor (IGF)-I and IGF-binding protein-3: evidence for an altered response to undernutrition in late-gestation following exposure to periconceptual undernutrition in the sheep. Journal of Endocrinology 159 501-508.

Gluckman PD 1984 Changing responsiveness to growth hormone releasing factor in the perinatal sheep. Journal of Developmental Physiology 6 509-515.

Gluckman PD, Mueller PL, Kaplan SL, Rudolph AM \& Grumbach MM 1979 Hormone ontogeny in the ovine fetus. III. The effect of exogenous somatostatin. Endocrinology 104 974-978.

Gluckman PD, Gunn AJ, Wray A, Cutfield WS, Chatelain PG, Guilbaud O, Ambler GR, Wilton P \& Albertsson-Wikland K 1992 Congenital idiopathic growth hormone deficiency associated with prenatal and early postnatal growth failure. The International Board of the Kabi Pharmacia International Growth Study. Journal of Pediatrics 121 920-923.

Gresham EL, James EJ, Raye JR, Battaglia FC, Makowski EL \& Meschia G 1972 Production and excretion of urea by the fetal lamb. Pediatrics 50 372-379.

Gull I \& Charlton V 1993 Effects of antipyrine on umbilical and regional metabolism in late-gestation in the fetal lamb. American Journal of Obstetrics and Gynecology 168 706-713.

Harding JE 1997 Prior growth rate determines the fetal growth response to acute maternal undernutrition in fetal sheep of late-gestation. Prenatal and Neonatal Medicine 2 300-309.

Harding JE, Evans PC \& Gluckman PD 1997 Maternal growth hormone treatment increases placental diffusion capacity but not fetal or placental growth in sheep. Endocrinology 138 5352-5358.

Heinrich UE 1992 Intrauterine growth retardation and familial short stature. Baillieres Clinical Endocrinology and Metabolism 6 589-601.

Hennies M, Breier BH, Gallaher BW, Krishnamurthi RV \& Gluckman PD 1998 Growth hormone induces electrolyte and metabolite imbalance in endotoxin challenged sheep. Proceedings of the 80th Annual Meeting of the Endocrine Society, p 144, abstract no. P1-108.

Herman A, Helman D, Livnah O \& Gertler A 1999 Ruminant placental lactogens act as antagonists to homologous growth hormone receptors and as agonists to human or rabbit growth hormone receptors. Journal of Biological Chemistry 274 7631-7639.

Kerscher L \& Ziegenhorn J 1985 Urea. In Methods of Enzymatic Analysis, vol 3, pp 444-453. Ed. HU Bergmeyer. Weinheim: Verlag Chemie.

Kim JD, Nanto-Salonen K, Szczepankiewicz JR, Rosenfeld RG \& Glassock GF 1993 Evidence for pituitary regulation of somatic growth, insulin-like growth factors-I and -II, and their binding proteins in the fetal rat. Pediatric Research 33 144-151.

Klempt M, Bingham B, Breier BH, Baumbach WR \& Gluckman PD 1993 Tissue distribution and ontogeny of growth hormone receptor messenger ribonucleic acid and ligand binding to hepatic tissue in the midgestation sheep fetus. Endocrinology 132 1071-1077.

Kulhanek JF, Meschia G, Makowski EL \& Battaglia 1974 Changes in DNA content and urea permeability of the sheep placenta. American Journal of Physiology 5 1257-1263.

Kunst A, Draeger B \& Ziegenhorn J 1984 Colorimetric methods with glucose oxidase and peroxidase. In Methods of Enzymatic Analysis, vol 3, pp 178-185. Ed. HU Bergmeyer. Weinheim: Verlag Chemie. 
Mellor DJ \& Murray L 1982 Effects on the rate of increase in fetal girth of refeeding ewes after short periods of severe undernutrition during late pregnancy. Research in Veterinary Science 32 377-382.

Meschia G, Cotter JR, Makowski EL \& Barron DH 1966 Simultaneous measurement of uterine and umbilical blood flows and oxygen uptakes. Quarterly Journal of Experimental Physiology 52 $1-18$.

Mesiano S, Young IR, Baxter RC, Hintz RL, Browne CA \& Thorburn GD 1987 Effect of hypophysectomy with and without thyroxine replacement on growth and circulating concentrations of insulin-like growth factors I and II in the fetal lamb. Endocrinology $1201821-1830$.

Morel PC, Blair HT, Ormsby JE, Breier BH, McCutcheon SN \& Gluckman PD 1994 Influence of fetal and maternal genotype for circulating insulin-like growth factor I on fetal growth in mice. Journal of Reproduction and Fertility 101 9-14.

Oliver MH, Harding JE, Breier BH, Evans PC \& Gluckman PD 1992 The nutritional regulation of circulating placental lactogen in fetal sheep. Pediatric Research 31 520-523.

Oliver MH, Harding JE, Breier BH, Evans PC \& Gluckman PD 1993 Glucose but not a mixed amino acid infusion regulates plasma insulin-like growth factor IGF-I concentrations in fetal sheep. Pediatric Research 34 62-65.

Oliver MH, Harding JE, Breier BH, Evans PC \& Gallaher BW 1995 The effects of ovine placental lactogen infusion on metabolities, insulin-like growth factors and binding proteins in the fetal sheep. Journal of Endocrinology 144 333-338.

Owens JA, Falconer J \& Robinson JS 1987 Effect of restriction of placental growth on fetal and utero-placental metabolism. Journal of Developmental Physiology 9 225-238.

Parkes MJ \& Bassett JM 1985 Antagonism by growth hormone of insulin action in fetal sheep. Journal of Endocrinology 105 379-382.

Pimentel G, Figueroa JP, Mitchell MD, Massmann A \& Nathanielsz PW 1986 Effect of fetal and maternal intravascular antipyrine infusion on maternal plasma prostaglandin concentrations in the pregnant sheep at 104 to 127 days' gestation. American Journal of Obstetrics and Gynecology 155 1181-1185.

Salomon F, Cuneo R \& Sonksen PH 1991 Growth hormone and protein metabolism. Hormone Research 36 41-43.

Stacey TE, Weedon AP, Haworth C, Ward RHT \& Boyd RDH 1978 Fetomaternal transfer of glucose analogs by sheep placenta. American Journal of Physiology 234 E32-E37.

Stevens D \& Alexander G 1986 Lipid deposition after hypophysectomy and growth hormone treatment in the sheep fetus. Journal of Developmental Physiology 8 139-145.

Received 24 September 1999

Revised manuscript received 12 May 2000

Accepted 26 May 2000 